\title{
THE MODEL OF PROFESSIONAL DEVELOPMENT \\ OF PHYSICAL TRAINING TEACHERS IN THE CONDITIONS OF POSTGRADUATE PEDAGOGICAL EDUCATION
}

\section{МОДЕЛЬ ПРОФЕСІЙНОГО РОЗВИТКУ ВЧИТЕЛІВ ФІЗИЧНОЇ КУЛЬТУРИ В УМОВАХ ПІСЛЯДИПЛОМНОї ПЕДАГОГІЧНОЇ ОСВІТИ}

\begin{abstract}
The model of professional development of physical training teachers in the conditions of postgraduate pedagogical education was analyzed in the article. It is developed in the form of a system that is holistic and interconnected and allows to design the professional development of physical training teachers in accordance with the needs of society and the requirements of employers, as well as for implementation its own individual educational trajectory in the conditions of postgraduate pedagogical education. The model, which we have developed is presented in five units: motivational and target, conceptual, theoretical and informative, organizational and developmental, evaluative and effective. The motivational and target unit of the model includes three components, namely: purpose, tasks and organizational and pedagogical conditions. The concept is the professional development of physical training teachers in the conditions of postgraduate pedagogical education. We have determined methodological approaches: individual and personal, system and activity, integrative, polysubjective, personalized and competent, acmeological and axiological, andragogical, and principles: systematic, professional context, dynamic, parity, interdisciplinarity. Theoretical and informative unit contains the developed professional program of advanced training of physical training teachers, thematic special course and educational and methodical complexes in medical and biological disciplines: "Morphofunctional bases of physical education and sport", "Medical and biological bases of physical education and sport", "Hygiene of physical education and sport", "Valeology". The organizational and developmental unit is represented by the following components: forms, methods, means. The evaluative and effective unit contains criteria and levels of professional development of physical training teachers in the conditions of postgraduate pedagogical education. The result of this model is the professional readiness of physical training teachers for educational activity in the conditions of postgraduate pedagogical education.

Key words: professional development, physical training teachers, postgraduate pedagogical education, continuous education.
\end{abstract}

У статті нами проаналізовано модель профресійного розвитку вчителів фрізичної куль- тури в умовах післядипломної педагогічноі освіти, яка розроблена у формі системи, що $є$ чілісною $і$ взаємозв'язаною та дає змогу спроєктувати професійне зростання вчителів фозичної культури відповідно до потреб суспільства й вимог роботодавців, а також для реалізації власної індивідуальної освітньої траєкторії в умовах післядипломної педагогічної освіти. Розроблена нами модель представлена п'ятьма блоками: мотиваційно-цільовим, концептуальним, теоретико-змістовним, організаційно-розвивальним та оцінювально-результативним. Мотиваційно-цільовий блок моделі включає три складники, а саме: мету, завдання та організаційно-педагогічні умови. Концепцією $є$ професійний розвиток учителів фрізичної культури в умовах післядипломної педагогічної освіти. Нами визначено методологічні підходи: індивідуально-особистісний, системно-діяльнісний, інтегративний, полісуб'єктний, персоналізовано-компетентнісний, акмеолого-аксіологічний, андрагогічний та принципи: системності, профресійної контекстності, динамічності, паритетності, міждисциплінарності та інтеграції, індивідуалізації та диференціації. Теоретико-змістовний блок містить розроблену профресійну програму підвищення кваліфрікації вчителів фрізичної культури, тематичний спецкурс та навчально-методичні комплекси з медикобіологічних дисциплін: «Морфро-срункціональні основи фрізичного виховання та спорт», «Медико-біологічні основи фрізичного виховання та спорту», «Гігієна фрізичного виховання і спорту», «Валеологія». Організаційно-розвивальний блок репрезентований такими складниками: фформи, методи, засоби. Оцінювально-результативний блок містить критерії та рівні профресійного розвитку вчителів фрізичної культури в умовах післядипломної педагогічної освіти. Результатом такої моделі $\epsilon$ профресійна готовність учителів фрізичноі культури до освітньої діяльності в умовах післядипломної педагогічної освіти.

Ключові слова: професійний розвиток, учителі фрізичної культури, післядипломна педагогічна освіта, неперервна освіта. University

Formulation of the problem in general. The socio-economic transformations that have taken place over the last twenty years have led to significant changes in various spheres of public life in our country. The labor market, which has become more dynamic and differentiated, has undergone a major modification. For the socially active part of the population of Ukraine, this has led to the need to constantly improve their own professional qualifications, intensified the need not only to develop new skills but also to acquire a new specialty through retraining. As we have noted in previous studies, today, every person has an awareness of the need for continuous education as a mechanism for successful social adaptation and self-realization in society [5, p. 78].

Analysis of recent research and publications. The analysis of the scientific and pedagogical literature shows that domestic and foreign scientists pay considerable attention to the issues of continuous education and professional development of teachers, namely: the problem of continuous professional education was studied by S. Arkhangelsky, Yu. Babansky, 
V. Lugovy; the theories of teacher's personality development in the conditions of continuous professional education - S. Goncharenko, N. Nichkalo, S. Sysoyeva, I. Fedotenko; the content of professional development of teachers was studied by foreign scientists - P. Benedzham, M. Dedles, S. Zepede, M. Riz; models, methods and forms of teachers' professional development - P. Grimmet, L. Evans, S. McLennen, J. Troy; M. Ben-Peretz, K. Prett, D. Sissen and others were involved in curriculum development for teachers' professional development. The issues of professional training of specialists in physical education and sports in the system of stage education were considered by scientists E. Zakharina, L. Denisova, Yu. Liannoi, V. Omelyanenko and others. Scientists (R. Klopov, L. Sushchenko, etc.) paid considerable attention to the development of the model of professional training of future specialists in the field of physical culture and sports. E. Pavlyuk, A. Svatiev considered the model of professional training of future coaches in the field of higher education.

Highlighting previously unresolved parts of a common problem. However, the professional development of physical training teachers in the conditions of postgraduate pedagogical education remains poorly understood.

The purpose of our work is to analyze the developed author's model of professional development of physical training teachers in the conditions of postgraduate pedagogical education.

Outline of the main research material. In the development and theoretical substantiation of the model of professional development of physical training teachers in the conditions of postgraduate pedagogical education, we relied on the position of scientists in the modeling and essence of models. In the Encyclopedia of Vocational Education, the term "model" is defined as an imaginary or materially implemented system that displays or reproduces a research object and is able to replace it so that its study provides new information about that object [4, p. 78]. In the "Great interpretative dictionary of contemporary Ukrainian language" the term "model" is interpreted as "an imaginary or conditional (image, description, scheme, etc.) image of any object, process or phenomenon used as its representative" [2, p. 683]. Yu. Babansky defines modeling as the highest and special form of visualization, a means of ordering information, which allows to reveal more thoroughly and more deeply the essence of the phenomenon which is being studied [3, p. 93]. E. Romanov interprets the concept of "pedagogical model" as a generalized, abstractly logical image of a particular phenomenon of the pedagogical system, which reflects and represents the essential structural and functional connections of the object of pedagogical research, presented in the required visual form and capable of providing new knowledge about the object of modeling [3].
The author's system of professional development of physical training teachers in the conditions of postgraduate pedagogical education is based on a model that is driven by the needs of society and employers' demands for the professional growth of physical training teachers in continuous education. In our study, the model of professional development of physical training teachers in the conditions of postgraduate pedagogical education is represented by five units: motivational and target, conceptual, theoretical and informative, organizational and developmental, evaluative and effective. This structure, in our opinion, makes it possible to systematically combine the purpose, tasks, content, forms, methods, means of organizing the educational process, the educational environment and, accordingly, the result, in other words, the professional readiness of physical training teachers for educational activity in the conditions of rapidly changing environment.

The motivational and target unit of the model includes three components, namely: purpose, tasks and pedagogical conditions.

The purpose is the professional development of physical training teachers in accordance with the actual and perspective needs of the individual, society and the state, which allows to create conditions for self-expression, self-determination, self-development of personality. Among the main complex tasks of professional development of physical training teachers in the conditions of postgraduate pedagogical education we define the following:

1. Creating the conditions for the compulsory and guaranteed acquisition of professional competences by physical training teachers necessary for them to perform the new functions.

2. Modernization of the educational process and improvement of the content of professional development of physical training teachers in the conditions of postgraduate pedagogical education.

3. Development of educational and methodological support for the educational process aimed at intensifying the professional development of physical training teachers in the conditions of postgraduate pedagogical education.

4. Promoting further professionalization of physical training teachers, including them in productive activities on the basis of acquired integration knowledge, skills and competences.

Let us consider the third component of the target unit of the model - organizational and pedagogical conditions that contribute to the intensification of the process of professional development of physical training teachers in the conditions of postgraduate pedagogical education, both at the level of structure and content, and at the level of technology of teaching. In this regard, it would be advisable to consider organizational and pedagogical conditions at three subcontracting levels. 
At the structure level, the first organizational and pedagogical condition is the openness of the educational environment of postgraduate pedagogical education institutions for the introduction of innovations in the process of professional development of physical training teachers. The work of these institutions should take into account the whole complex of changes in education: intensification of the educational process, new content and forms of its organization, socio-cultural and value reorientation of education, new strategies in the management and financing of educational institutions.

In search of new approaches to organizing the process of professional development of physical training teachers in postgraduate teacher education, it is important to reflect not only the external changes caused by the educational environment but also the internal ones, which are connected with the necessary changes in the activity of teachers. In connection with this second organizational and pedagogical condition at the level of structure is the andragogical competence of the teachers, who provide the process of professional development of physical training teachers in the conditions of postgraduate pedagogical education.

At the content level, the organizational and pedagogical condition is the selection and structuring of the content of education of professional development of physical training teachers in the conditions of postgraduate pedagogical education in accordance with the integration processes.The transition from the qualification model of the specialist to the competency allowed to shift the emphasis in the professional development of physical training teachers in the conditions of postgraduate pedagogical education to social, personal, academic and professional competences. Accordingly, information and knowledge that provide the opportunity for specialization in the field of physical culture and sports, required not only in the market of educational services, but also in the labor market, can not be academically closed, rigidly delimited.

At the level of the technology of teaching, the first organizational and pedagogical condition is the integrally-differentiated organization of classes in the process of professional development of physical training teachers in the conditions of postgraduate pedagogical education using modern teaching technologies.

The processes of integration and differentiation complement each other, exist in unbroken unity and are a dialectical interrelationship on a common logical and methodological basis. In the conditions of postgraduate pedagogical education, these processes contribute to the successful acquisition of basic skills and professional competences.

The second organizational and pedagogical condition at the level of the technology of teaching is the regular change of the nature of activity in the process of professional development with the emphasis on the personal experience of the students and their individual motivational orientation (Pic. 1).

The professional development of physical training teachers in the conditions of postgraduate pedagogical education needs to be improved, first of all, in the field of teaching technology. In the conditions of system updating it is necessary to incorporate in the technology of training a modification of their various parameters in view of the psychology of the trainees, the purpose of education and the conditions of study, as well as the available means of training.

The conceptual unit of the model is represented by the concept of professional development of physical training teachers in the conditions of postgraduate pedagogical education, as well as methodological approaches and principles of its realization.

Let's start with the concept of professional development of physical training teachers in the conditions of postgraduate pedagogical education in which in our research in the conditions of modern integration processes the leading ideas define the professional development and becoming of the physical training teacher as a full-fledged subject of professional pedagogical activity; formation of personal position of physical training teacher in accordance with the specialties; development of the need for continuous education during the further professional activity. The implementation of the developed concept (in components: purpose, tasks, principles, system-forming components and organizational and pedagogical conditions) will be the basis of the system modernization of postgraduate pedagogical education, which will provide coordinated development of its components, horizontal and vertical interaction of different educational structures; enrich the content, forms and methods of the educational process.

Methodological approaches of professional development of physical training teachers in the conditions of postgraduate pedagogical education are defined as follows:

- system and activity (studying and modeling of holistic process of productively oriented professional development of physical training teachers in the conditions of postgraduate pedagogical education in the interrelation of components, its analysis from the point of view of integrity, system characteristics and basic system qualities; understanding of regularities of professional qualification);

- individual and personal (initiative position of physical training teachers, taking into account their psychosocial and physical characteristics, development of the content of each specific stage of learning in the interconnected context of the content, structure and technologies of learning, which will lead to conscious, strong assimilation of their competence and new professional competence); 


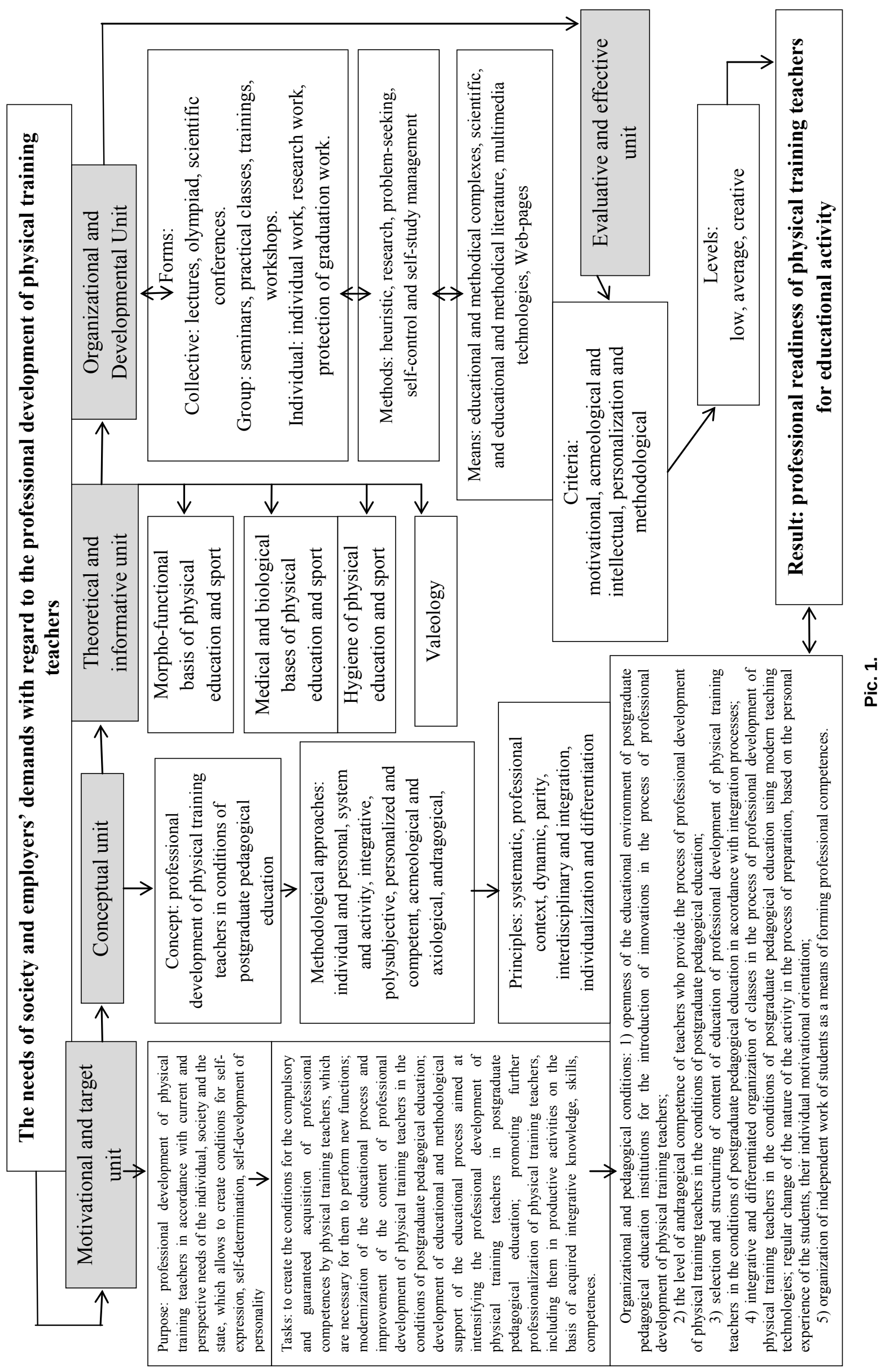


- integrative (the relationship between professional, medical, biological, psychological and pedagogical, social and humanitarian disciplines in the integrated system "education - physical culture healthy lifestyle");

- polysubjective (belief in the positive potential of each knowledge-seeker, his individual unlimited capacities, awareness of the need for continuous development and self-improvement within certain social groups in the context of dialogical relations with others);

- personalized and competent (defining personal educational trajectory through portfolio development and isolation of existing dominant and new competences, flexible educational environment to meet individual needs and achievement of results, competence covers not only cognitive and operational-technological components, but also ethical, social, motivational, behavioral, it contains learning outcomes, a system of value orientations, so competences are formed not only during training, but also under the influence of society);

- acmeological and axiological (strengthening of professional motivation, creative potential; identification and realization of own resources for maintenance of professional success, formation of strong interest and ability to study, desire to improve life; ability to make prudent choice and to set goals, modern self-specific goals activities, improve social and civic competences);

- andragogical (mastery of knowledge, skills, qualities, qualities and value orientations necessary for fulfilling the role of an andragog while conducting classes with an adult audience; development of socially significant qualities of an adult through educational activitiy by means of the use of educational process technologies and educational processes features of thinking and emotional-volitional sphere of listeners).

Professional development of physical training teachers in the conditions of postgraduatepedagogical education is carried out in accordance with the principles of:

- systematic, which presupposes unity of differentiation, integration and hierarchical organization of professional development of physical training teachers in the conditions of postgraduate pedagogical education;

- professional context, which implies the unity of the abilities, theoretical and practical readiness of physical training teachers to carry out productive pedagogical activities;

- dynamic, that allows for changes and additions to the content of educational programs;

- parity, based on subject and subjective interaction between teachers and students;

- interdisciplinarity and integration, which focuses on the selection and structuring of teaching material for the synthesis of knowledge from a wide range of sciences that are related to the teacher's professional and pedagogical activity;

- individualization and differentiation aimed at considering the needs, interests and abilities of the listeners, the experience of their pedagogical activity and basic professional education.

Theoretical and informative unit contains the developed professional program of advanced training of physical training teachers, thematic special course and educational and methodical complexes in medical and biological disciplines: "Morphofunctional bases of physical education and sport", "Medical-biological bases of physical education, sports", "Hygiene of physical education and sport", "Valeology".

The organizational and developmental unit is represented by the following components: forms, methods, means.

Among the forms of professional development of physical training teachers

in the conditions of postgraduate pedagogical education we define the following: collective: lectures, olympiads, scientific conferences, conferences on exchange of experience, forums and educational conventions concerning physical culture and sports; group: seminars, practical classes, pedagogical trainings, problematic discussions, scientific circles, workshops, sports sections, clubs, professional competitions; individual: independent work, research work, individual and educational training, writing and defense of the master's coursework and graduation, etc.

The methods in the context of our study include the following components: heuristic and verbal (explanation, lecture, story, heuristic conversation); problem search (interviewing, conversation, discussion, testing, modeling, designing and redesigning activities, round table, role-playing games, consideration of specific professional situations, video method, case-study method); research (search, research, diagnostic, visual, control and self-control, stimulation of creative activity, methods of facilitation); self-control and management of selfstudy (elaboration of scientific and methodological literature; preparation of reports for participation in conferences, seminars, articles for publication in national and international publications; development of individual educational trajectory, preparation and continuous accumulation of portfolios).

The means of training during the professional development of physical training teachers we have defined: sports equipment, educational and methodical complexes (courses of lectures, plans of practical trainings, tests, means of diagnostics and assessment, materials for questionnaire), scientific and educational-methodical literature (textbooks, educational and tutorials, guidelines), multimedia technologies, web pages, web-tutorials, computer and multimedia support, interaction in professional networks (infor- 
mation and educational portals and web sites of physical training teachers, remote platforms, online libraries, blogs, etc.).

The evaluative and effective unit contains criteria and levels of professional development of physical training teachers in the conditions of postgraduate pedagogical education. Within our study, the criteria include motivational (positive attitude to the subjects of the educational process, society as a whole, value orientations, positive motivation through professional self-organization with minimal influence of external educational factors), acmeological and intellectual (personal harmony with personality) self-formation, ethical and aesthetic development, assertiveness, energy and vitality, creation of one's own life and improvement of the existing world), personalization and methodological (psychic self-regulation, individual and psychological features (temperament, character, social type), professionally important qualities and abilities, knowledge efficiency, analytical skills, pedagogical and psychological and methodological competence). Levels of professional development of physical training teachers in the conditions of postgraduate pedagogical education: low, average, creative. Let's take a closer look at each of them.

The low level is characterized by fragmentary knowledge in medical and biological disciplines. Students at this level are characterized by a lack of awareness of the acquired knowledge, a low level of their actualization, involuntary mastery of mental operations, lack of certainty, consistency. Skills in the medical and biological disciplines are poor. Listeners need external stimuli, they have lack of independence, and in practice, knowledge and skills are misused. There is no creative self-realization, the need for success often does not arise.

The intermediate level is characterized by systematic and fragmentary knowledge of medical and biological disciplines. Listeners at this level are characterized by the ability to make judgments and draw conclusions by analogy; the initiative is not sufficiently expressed. Skills in medical and biological disciplines are partially expressed, which are required the further improvement. They are applied at the reproductive level and in standard situations. The autonomy of the students is not sufficiently developed.

The creative level is characterized by strong, systematic, scientific and structured knowledge of medical and biological disciplines. At this level, the students have sufficiently mastered theoretical material in the medical and biological disciplines and have developed practical skills. They show a high level of creative interaction, readiness for self-education, a steady interest in the need to use knowledge of medical and biological disciplines in future professional activity. The students demonstrate a high level of personal activity, unpretentious thinking, formed creative competence. The result of this model is the professional readiness of physical training teachers for educational activity in the conditions of postgraduate pedagogical education.

Conclusions and further prospects of research in this direction. Thus, we have analyzed the model of professional development of physical training teachers in postgraduate pedagogical education. The model is developed in the form of a system that is holistic and interconnected and allows to design the professional development of physical training teachers in accordance with the needs of society and employers realization of own individual educational trajectory in the conditions of postgraduate pedagogical education.

\section{REFERENCES}

1. Бабанский Ю.К. Оптимизация учебно-воспитательного процесса: метод. основы. Москва : Просвещение. 1982. 192 с.

2. Великий тлумачний словник сучасної української мови. / Бусел В.Т., головний редактор. Київ; Ірпінь : Перун; 2005. 1728 с.

3. Романов Е.В. Теория и практика профессиональной подготовки учителя технологии и предпринимательства : монограффия. Магнитогорск : МАГУ. 2001. 245 c.

4. Энциклопедия профессионального образования: в 3-х т. / под ред. С.Я. Батышева. Москва : Изд-во Акад. проф. образования, 1999. Т. 2. 440 с.

5. Voitovska O., Tolochko S., Bordyug N. Lifelong learning in modern strategies of sustainable development. Studia Warminskie. Volume 55, 2018. C. 343-352. 